\title{
UJI IN VITRO AKTIVITAS ANTIBAKTERI EKSTRAK CANGKANG BIJI KARET DAN BIJI KARET TERHADAP Aeromonas hydrophila
}

\section{IN VITRO TEST OF ANTIBACTERIAL ACTIVITY OF SHELL AND RUBBER SEED EXTRACTS AGAINST Aeromonas hydrophila}

\author{
Hilma Putri Fidyandini ${ }^{1, *}$, Lisa Silviana ${ }^{1}$ \\ ${ }^{1}$ Program Studi Budidaya Perairan, Fakultas Pertanian, Universitas Lampung, Lampung, Indonesia \\ •email penulis korespondensi: hilma.putri@fp.unila.ac.id
}

\begin{abstract}
Abstrak
Ikan lele merupakan salah satu komoditas perikanan unggulan di Indonesia yang saat ini banyak menggunakan teknologi budidaya secara intensif. Salah satu masalah dalam budidaya lele adalah serangan bakteri Aeromonas hydrophila yang dapat menyebabkan penyakit Motile Aeromonas Septicemia. Informasi mengenai aktivitas antibakteri Aeromonas hydrophila ekstrak cangkang dan biji karet belum diketahui, oleh karena itu perlu dilakukan penelitian mengenai aktivitas antibakteri ekstrak cangkang dan biji karet terhadap bakteri pathogen Aeromonas hydrophila. Metode penelitian ini meliputi persiapan sampel, ekstraksi, uji fitokimia, persiapan suspensi bakteri, uji antibakteri dengan metode difusi agar, uji Minimum Inhibitory Concentration. Hasil penelitian menunjukkan bahwa ekstrak cangkang biji karet mengadung senyawa antibakteri saponin, terpenoid dan flavonoid. Sedangkan ekstrak biji karet mengandung senyawa terpenoid dan flavonoid. Ekstrak cangkang dan biji karet pada konsentrasi 0,5-4 mg/mL menunjukkan daya hambat yang sangat lemah.
\end{abstract}

Kata Kunci: Biji karet, Cangkang biji karet, Antibakteri, Aeromonas hydrophila

\begin{abstract}
Catfish is one of leading fishery commodity in Indonesia that nowadays is using intensive technology. One of the problems in cultivating catfish is the invasion of bacteria Aeromonas hyprophila which can cause Motile Aetomonas Septicemia disease. Information regarding the antibacterial activity of shell and rubber seed extract on Aeromonas hydrophila is not yet known. Therefore it is necessary to do a research about the antibacterial activities of the shell and rubber seed extract against the pathogenic bacteria, Aeromonas hydrophila. This research method was sample preparation, extraction, phytochemical test, preparation of bacterial suspension, antibacterial test with agar diffusion method, minimum inhibitory concentration test. The result shows that the rubber seed shell extract contains antibacterial compounds such as saponin, terpenoids and flavonoids. While the rubber seed extract contains terpenoid and flavonoid compounds. The shell and rubber seed extract at a concentration of $0.5-4 \mathrm{mg} / \mathrm{mL}$ showed very weak inhibition.
\end{abstract}

Keywords: Rubber seed, Rubber seed shell, Antibacterial, Aeromonas hydrophila

\section{PENDAHULUAN}

Ikan lele merupakan salah satu komoditas perikanan unggulan di Indonesia. Teknologi budidaya ikan lele yang banyak digunakan adalah budidaya intensif. Sama seperti usaha budidaya perikanan lainnya, masalah utama dalam budidaya ikan lele adalah serangan penyakit. Kematian ikan lele dan kegagalan panen akan dialami jika serangan penyakit tidak ditanggulangi secara dini. Untuk menghindari keadaan ini, perlu dilakukan upaya pencegahan dan penanggulangan penyakit secara tepat.
Aeromonas hydrophila merupakan salah satu bakteri yang banyak ditemukan di perairan tawar di seluruh dunia yang merupakan patogen di lingkungan budidaya maupun perairan umum (Shayo et al., 2012). Penyakit bakterial pada ikan, khususnya yang disebabkan oleh Aeromonas hydrophila, mulai dikenal di Indonesia sejak tahun 1980, yang menyebabkan penyakit Motile Aeromonas Septicemia (MAS). Pada tahun tersebut bakteri ini menyebabkan wabah penyakit ikan karper di Jawa Barat, dan mengakibatkan kematian ikan sebanyak 125 ton. 
Penanganan penyakit MAS dilakukan dengan berbagai jenis antibiotika tertentu seperti oxytetracyclin, chloramphenicol, erythromycin, kanamycin, dan rimfamicin. Namun, penggunaan antibiotika dalam jangka waktu lama, dapat berdampak negatif yaitu bakteri dapat menjadi resisten.

Resistensi merupakan masalah yang sering timbul dalam pengobatan penyakit infeksi. Peningkatan resistensi bakteri terhadap antibiotik memberikan peluang besar untuk mendapatkan senyawa antibakteri dengan memanfaatkan senyawa bioaktif dari keanekaragaman tanaman yang ada di Indonesia. Provinsi Lampung merupakan salah satu Provinsi yang memiliki produksi tanaman karet cukup tinggi, menurut data Badan Pusat Statistik Provinsi Lampung, produksi tanaman karet perkebunan rakyat tahun 2014 sebesar 52.050 Ton.

Tanaman karet memiliki hasil sampingan yaitu biji karet yang belum dimanfaatkan. Biji karet selama ini dianggap tidak memiliki nilai ekonomis, hanya dimanfaatkan sebagai benih generatif pohon karet. Selebihnya terbuang siasia. Secara fisik cangkang biji karet memiliki ciri konstruksi cangkang yang keras mengindikasi bahwa cangkang biji karet ini mengandung senyawa berupa selulosa hemiselulosa dan lignin. Menurut Haulia et al., (2018), cangkang biji karet memiliki daya awet yang tinggi sehingga tidak cepat membusuk meskipun berada di tempat terbuka. Hal ini menunjukkan bahwa cangkang biji karet memiliki senyawa antibakteri yang mampu menekan pertumbuhan jamur dan bakteri.

Penelitian Luthfiyah (2017) menunjukkan bahwa asap cair cangkang biji karet memiliki aktifitas antibakteri terhadap Bacillus sp. dan E. coli, penelitian tersebut juga menunjukkan bahwa asap cair cangkang biji karet mengandung komponen kimia diantaranya senyawa yang paling mendominasi adalah asam asetat, phenol, 2-methoxy, phenol,2-methoxy-4-methyl, dan 2furancarboxaldehyde. Informasi mengenai aktivitas antibakteri Aeromonas hydrophila pada ekstrak cangkang dan biji karet belum diketahui, oleh karena itu perlu dilakukan penelitian mengenai aktivitas antibakteri ekstrak cangkang dan biji karet terhadap bakteri pathogen Aeromonas hydrophila.

\section{MATERI DAN METODE}

\section{Alat dan Bahan}

Alat yang dugunakan dalam penelitian ini atara lain cawan petri, tabung erlenmayer, oven, timbangan digital, tabung reaksi, pipet tetes, rotary evaporator, jarum ose, magnetic stirer, dan inkubator. Bahan yang digunakan antara lain
Bakteri Aeromonas hydrophila, cangkang dan biji karet, media Trypticase Soy Agar (TSA), Trypticase Soy Broth (TSB), kertas saring, akuades, asam asetat glacial, $\mathrm{H}_{2} \mathrm{SO}_{4}$, larutan $\mathrm{FeCl}_{3}$, klorofoam, $\mathrm{KI}, \mathrm{HgCl}_{2}$, serbuk $\mathrm{Mg}$ dan $\mathrm{HCl}$ pekat.

\section{Metode Penelitian}

\section{a. Persiapan Sampel}

Biji karet dikoleksi dari kebun karet rakyat di Mesuji, Provinsi Lampung. Biji karet dimasukkan ke dalam box tanpa penutup untuk menghindari biji karet lembab. Kemudian biji karet dicuci dan dipisahkan dari cangkangnya. Biji dan cangkang dipotong-potong kemudian dioven pada suhu $100{ }^{\circ} \mathrm{C}$ selama 4 jam kemudian bahan yang sudah kering digiling sehingga didapatkan simplisia cangkang biji karet dan simplisia biji karet.

\section{b. Ekstraksi}

Simplisa cangkang biji karet dan biji karet yang diperoleh dilakukan maserasi dengan etanol 96\% selama 24 jam dengan perbandingan bahan dan pelarut 1:10 w/v. Ekstrak yang dihasilkan kemudian disaring dan dievaporasi pada suhu $41,3^{\circ} \mathrm{C}$ dengan kecepatan $121 \mathrm{rpm}$ untuk mendapatkan filtrat dan residu hingga diperoleh hasil ekstrak. Setelah dievaporasi, ekstrak yang dihasilkan dimasukan ke dalam botol kaca yang sudah ditutup dengan plastik lalu disimpan di lemari pendingin.

\section{c. Uji Fitokimia}

Uji fitokimia dilakukan di Laboratorium Kimia Organik, Universitas Lampung. Uji kualitatif fitokimia meliputi Saponin, Steroid, Terpenoid, Tanin, Alkaloid dan Flavonoid. Metode yang digunakan menurut Tasmin et al., (2014).

\section{d. Persiapan Suspensi Bakteri}

Bakteri uji yang digunakan adalah bakteri Aeromonas hydrophila yang diperoleh dari sediaan Balai Karantia Ikan dan Penjaminan Mutu Lampung. Biakan $A$. hydrophila dalam agar miring diambil secara aseptic kemudian dipindahkan di media agar untuk mendapatkan biakan satu koloni, dan diinkubasi selama 24 jam. Setelah mendapatkan satu koloni, biakan diambil dengan menggunakan jarum osse dan dipindahkan ke media cair Triptycase Soy Agar (TSA) diinkubasi selama 24 jam. Jumlah sel A. hydrophila yang telah diinkubasi diukur menggunakan spektrofotometer hingga mencapai $10^{8} \mathrm{sel} / \mathrm{mL}$. 


\section{e. Uji Aktivitas Antibakteri Metode Difusi Agar}

Uji aktivitas antibakteri dilakukan dengan metode difusi agar menggunakan kertas cakram/ saring (paper disc) berdiameter $6 \mathrm{~mm}$ dengan bakteri uji $A$. hydrophila. Uji aktivitas antibakteri dilakukan dengan tiga kali pengulangan. Paper disc dicelupkan ke dalam sampel dengan konsentrasi $0,5,1,2$, dan $4 \mathrm{mg} / \mathrm{mL}$, kemudian diletakkan di atas media TSA yang telah diinokulasikan $100 \mu \mathrm{l}$ isolat cair $A$. hydrophila dengan kepadatan $10^{8} \mathrm{sel} / \mathrm{mL}$. Inkubasi dilakukan pada suhu $37^{\circ} \mathrm{C}$ selama 24 jam. Pengamatan dilakukan terhadap terbentuknya zona hambat di sekitar paper disc. Perlakuan kontrol pada uji ini menggunakan antibiotik yaitu oxytetracyclin.

\section{f. Uji Aktivitas Antibakteri dengan Metode Minimum Inhibitory Concentration}

Minimum Inhibitory Concentration (MIC) dilakukan dengan menggunakan metode serial tube dillution. Uji MIC dilakukan dengan membuat larutan ekstrak dengan konsentrasi 0,5, 1, 2, dan $4 \mathrm{mg} / \mathrm{mL}$ pada media cair Trypticase Soy Broth (TSB). Tabung reaksi yang digunakan sebagai wadah diisi TSB sebanyak 10 $\mathrm{ml}$ lalu ditambahkan ekstrak cangkang biji karet dan biji karet dengan konsentrasi 0,5, 1, 2, dan 4 $\mathrm{mg} / \mathrm{mL}$ pada masing-masing tabung lalu diinokulasi bakteri patogen $A$. hydrophila dengan kepadatan $10^{8} \mathrm{cfu} / \mathrm{ml}$, diinkubasi selama 24 jam. Penentuan ekstrak yang efektif menghambat pertumbuhan bakteri $A$. hydrophila konsentrasi terendah yang dapat menghambat pertumbuhan A. hydrophila dilihat dari kekeruhan tabung reaksi uji. Perlakuan kontrol pada uji MIC menggunakan antibiotik oxytetracycline.

\section{HASIL}

Hasil uji kualitatif fitokimia ekstrak cangkang biji karet dan biji karet dapat dilihat pada Tabel 1. Tabel 2 merupakan Hasil uji aktivitas antibakteri dan Tabel 3 merupakan hasil uji MIC.

Tabel 1. Hasil uji kualitatif fitokimia ekstrak cangkang biji karet dan biji karet

\begin{tabular}{llccc}
\hline \multirow{2}{*}{ No. } & \multirow{2}{*}{$\begin{array}{c}\text { Jenis Uji Kualitatif } \\
\text { Fitokimia }\end{array}$} & $\begin{array}{c}\text { Ekstrak Cangkang } \\
\text { Biji Karet }\end{array}$ & $\begin{array}{c}\text { Ekstrak Biji } \\
\text { Karet }\end{array}$ & Hasil pengamatan bila $(+)$ \\
\hline 1. & Saponin & + & - & Terbentuk busa \\
\hline 2. & Steroid & - & - & Warna sampel berubah menjadi ungu atau biru \\
\hline 3. & Terpenoid & + & + & Warna sampel berubah menjadi merah atau kuning \\
\hline 4. & Tanin & - & - & Warna larutan hitam kebiruan \\
\hline 5. & Alkaloid & - & - & Warna larutan putih kecokelatan \\
\hline 6. & Flavonoid & + & + & Warna larutan merah/kuning dan ada busa. \\
\hline
\end{tabular}

Tabel 2. Hasil uji aktivitas antibakteri dengan metode difusi agar

\begin{tabular}{|c|c|c|c|c|c|}
\hline \multirow{2}{*}{ Ekstrak } & \multicolumn{5}{|c|}{ Perlakuan } \\
\hline & Kontrol & $0,5 \mathrm{mg}$ & $1 \mathrm{mg}$ & $2 \mathrm{mg}$ & $4 \mathrm{mg}$ \\
\hline Cangkang biji karet & $12,49 \pm 0,0$ & $0,22 \pm 0,02$ & $1,9 \pm 0,62$ & $2,53 \pm 1,4$ & $2,52 \pm 0,15$ \\
\hline Biji Karet & $12,49 \pm 0,0$ & $0,6 \pm 0,14$ & $3,92 \pm 0,16$ & $3,6 \pm 1,8$ & $4,65 \pm 0,8$ \\
\hline
\end{tabular}

Tabel 3. Hasil uji MIC

\begin{tabular}{|c|c|c|c|c|c|}
\hline \multirow{2}{*}{ Ekstrak } & \multicolumn{5}{|c|}{ Perlakuan } \\
\hline & Kontrol & $0,5 \mathrm{mg}$ & $1 \mathrm{mg}$ & $2 \mathrm{mg}$ & $4 \mathrm{mg}$ \\
\hline Cangkang biji karet & - & + & + & + & + \\
\hline Biji Karet & - & + & + & + & - \\
\hline
\end{tabular}

Keterangan: tanda (-) menunjukan media TSB yang jernih; tanda (+) menunjukan media TSB yang keruh.

\section{PEMBAHASAN}

\section{Uji Fitokimia}

Berdasarkan hasil uji kualitatif fitokimia, ekstrak cangkang biji karet mengandung senyawa saponin, terpenoid dan flavonoid. Sedangkan ekstrak biji karet mengandung senyawa terpenoid dan flavonoid. Senyawa falvonoid terdapat dalam ekstrak cangkang dan biji karet. Mekanisme kerja senyawa flavonoid sebagai anti bakteri dapat dibagi menjadi tiga yaitu menghambat sintesis asam nukleat, menghambat fungsi membrane dan sel, serta menghambat metabolisme energi (Hendra et al., 2011).

Menurut Cushnie dan Lamb (2005), dalam meghambat sintesis asam nukleat, cincin A dan B senyawa Flavonoid berperan penting dalam proses interkelasi atau ikatan hidrogen yakni dengan menumpuk basa asam nukleat sehingga menghambat pembentukan DNA dan RNA. Hasil interaksi Flavonoid juga akan menyebabkan kerusakan permeabilitas dinding sel. Dalam menghambat fungsi membran sel, Flavonoid akan membentuk senyawa kompleks dari protein ekstraseluler dan terlarut sehingga membran sel rusak dan senyawa intraseluler keluar. Di dalam 
menghambat metabolisme energi, flavonoid menghambat penggunaan oksigen oleh bakteri, yaitu dengan mencegah pembentukan energi pada membrane sitoplasma dan menghambat motilitas bakteri yang berperan dalam aktivitas antimikroba dan protein ekstraseluler.

Hasil uji fitokimia menunjukkan bahwa hanya ekstrak cangkang biji karet yang mengandung senyawa saponin. Senyawa Saponin merupakan senyawa antibakteri yang dapat menyebabkan kebocoran protein dan enzim dari dalam sel (Madduluri et al., 2013). Saponin berdifusi melalui membran luar dan dinding sel yang rentan kemudian mengikat membran sitoplasma sehingga mengganggu dan mengurangi kestabilan membran sel. Hal ini menyebabkan sitoplasma bocor keluar dari sel yang mengakibatkan kematian sel. Agen antimikroba yang mengganggu membran sitoplasma bersifat bakterisida (Cavalieri et al., 2005). Keberadaan saponin dalam cangkang biji karet tersebut menyebabkan daya awet yang tinggi sehingga tidak cepat membusuk meskipun berada di tempat terbuka dibandingkan dengan biji karet.

Senyawa terpenoid terdapat dalam cangkang dan biji karet. Mekanisme kerja senyawa terpenoid sebagai zat antibakteri diduga melibatkan kerusakan membran oleh senyawa lipofilik (Cowan, 1999). Terpenoid dapat bereaksi dengan porin (protein transmembran) pada membran luar dinding sel bakteri, membentuk ikatan polimer yang kuat dan merusak porin, mengurangi permeabilitas dinding sel bakteri sehingga sel bakteri kekurangan nutrisi, pertumbuhan bakteri terhambat atau mati (Rahmawati et al., 2011).

\section{Uji Aktivitas Antibakteri dengan Metode Difusi Agar}

Adanya aktivitas antibakteri ditunjukkan dengan terbentuknya zona hambat di sekitar paper disc. Terbentuknya hambatan menurut Purnobasuki dan Suzuki (2004) disebabkan adanya kandungan senyawa yang bersifat antibakteri seperti flavonoid dengan fungsi menghambat pertumbuhan bakteri, senyawa terpenoid yang menyebabkan kerusakan membran oleh senyawa lipofilik, dan senyawa saponin yang menyebabkan kebocoran protein dan enzim dari dalam sel bakteri. Sifat aktivitas antibakteri ditentukan berdasarkan diameter zona hambat, dimana zona hambat yang dihasilkan dalam penelitian ini termasuk kategori sangat lemah.

Menurut Muharni et al., (2017) suatu antibakteri/antibiotik dikatakan mempunyai aktivitas terhadap bakteri jika mempunyai kekuatan sebagai berikut apabila memberikan nilai zona hambat dengan ukuran 6-10 mm dikategorikan lemah, 11-20 mm dikategorikan aktif, dan 21-30 $\mathrm{mm}$ atau lebih dikategorikan sangat aktif.

\section{Uji Minimum Inhibitory Concentration}

Uji MIC merupakan pengujian yang bertujuan untuk mengetahui dosis atau konsentrasi terendah dari ekstrak yang dapat menghambat pertumbuhan bakteri uji (Pratiwi, 2009). Berdasarkan hasil Tabel 3 diatas yang menyajikan hasil uji MIC diperoleh pada konsentrasi kontrol dengan menggunakan antibiotik oxytetracycline menunjukan media TSB yang digunakan pada pengujian memperoleh warna yang jernih. Media TSB yang juga menunjukan warna yang jernih yaitu pada konsentrasi ekstrak $4 \mathrm{mg}$. Warna media jernih pada perlakuan menunjukan tidak adanya pertumbuhan bakteri $A$. hydrophila. Sedangkan pada konsentrasi 0,5-4mg ekstrak cangkang menunjukan media TSB yang keruh, yang menunjukkan masih adanya pertumbuhan bakteri. Hasil jernih yang diperoleh sesuai dengan pernyataan menurut Pratiwi (2009) media cair TSB yang terlihat jernih setelah masa inkubasi antara 18-24 jam ditetapkan sebagai nilai MIC. Perbedaan hasil yang diperoleh menurut Brooks et al., (2005) semakin tinggi suatu konsentrasi yang digunakan dalam uji maka semakin besar komponen senyawa aktif yang terkandung didalamnya sehingga hasil hambatan yang diperoleh berbeda pada setiap konsentrasinya.

\section{KESIMPULAN}

Berdasarkan hasil penelitian menunjukkan bahwa ekstrak cangkang biji karet mengadung senyawa Saponin, Terpenoid dan Flavonoid. Sedangkan ekstrak biji karet mengandung senyawa Terpenoid dan Flavonoid. Ekstrak cangkang dan biji karet pada konsentrasi 0,5-4 $\mathrm{mg} / \mathrm{ml}$ menunjukkan daya hambat yang sangat lemah.

\section{DAFTAR PUSTAKA}

Brooks GF, Butel JS, Morse SA, Eddy MH. 2005. Mikrobiologi Kedokteran. Salemba Medika, Jakarta. 2005. ISBN: 9793027045.

Cavalieri SJ, Rankin ID, Harbeck RJ, Sautter RS, McCarter YS, Sharp SE, Ortez JH, Spiegel CA. 2005. Manual of Antimicrobial Susceptibility Testing. USA: American Society for Microbiology

Cowan MM. 1999. Plant products as antimicrobial agents. Clinical Microbiology Reviews 12(4): 564-582 
Cushnie TP, Lamb AJ. 2005. Antimicrobial activity of flavonoids. International Journal of Antimicrobial Agents 26(5): 343-356

Haulia DP, Sumpono, Nurhamidah. 2018. Uji Aktivitas Asap Cair Cangkang Buah Karet (Hevea brassiliensis) dan Aplikasinya Dalam Penghambatan Ketengikan Daging Sapi. Jurnal Pendidikan dan Ilmu Kimia 2 (2): 97105

Hendra R, Ahmad S, Sukari A, Shukor MY, Oskoueian E. 2011. Flavonoid analyses and antimicrobial activity of various parts of Phaleria macrocarpa (Scheff.) Boerl fruit. Int J Mol Sci 12(6): 3422-3431.

Luthfiyah N. 2017. Uji Aktivitas Antibakteri Asap Cair Dari Cangkang Biji Karet (Hevea brasiliensis) Terhadap Bacillus Sp. dan Escherichia Coli Serta Analisis Komponen Kimianya. [Skripsi]. Fakultas Matematika dan Ilmu Pengetahuan Alam. Universitas Lampung.

Madduluri S, Rao KB, Sitaram B. 2013. In vitro evaluation of antibacterial activity of five indegenous plants extract against five bacterial pathogens of human. International Journal of Pharmacy and Pharmaceutical Sciences 5(4): 679-684

Muharni M, Fitrya F, Farida S. 2017. Uji aktivitas antibakteri ekstrak etanol tanaman obat Suku Musi di Kabupaten Musi Banyuasin,
Sumatera Selatan. Jurnal Kefarmasian Indonesia 7(2): 127-135

Pratiwi ST. 2009. Mikrobiologi Farmasi. Erlangga, Jakarta. ISBN : 9789790334557

Purnobasuki, H., and Suzuki, M. 2004. Aerenchyma formation and porosity in root of a mangrove plant, Sonneratia alba (Lythraceae). Journal of Plant Research 117(6): 465-472.

Rachmawati F, Nuria MC, Sumantri. 2011. Uji aktivitas antibakteri fraksi kloroform ekstrak etanol pegagan (Centella asiatica (L) Urb) serta identifikasi senyawa aktifnya. Abstrak Seminar Nasional Peranan dan Kontribusi Herbal dalam Terapi Penyakit Degeneratif 17 Desember 2011. Prosiding ISBN: 978-602-19556-0-4. Fakultas Farmasi Universitas Wahid Hasyim. Semarang

Shayo SD, Mwita CJ and Hosea K. 2012. Ulcerative Aeromonas Infections in Tilapia (Cichlidae: Tilapiini) from Mtera Hydropower Dam, Tanzania. Journal of Marine Science: Research \& Development 1 (1): 115-119.

Tasmin, N., Erwin, dan Kusuma, I.W. 2014. Isolasi, identifikasi dan uji toksisitas senyawa flavonoid fraksi kloroform dari daun terap (Artocarpus odoratissi-mus blanco). Jurnal Kimia Mulawarman 12(1): 45-52. 